\title{
Centres for Education
}

This year is the 25th anniversary of the Christ Church Conference at Oxford, chaired by Sir George Pickering, at which the postgraduate centre movement was born. It was not, as people with short memories seem to think, the beginning of postgraduate medicine for all in this country, but it did provide a welcome boost for a band of enthusiastic teachers already at work in what came to be known as district hospitals.

A detailed history of postgraduate medical education in Britain needs to be written. Both Osler and Allbutt (Allbutt, 1906), those two medical giants who spanned the turn of the century, lectured about the need, not only for instruction but also for dedicated institutions and professorial academic units. By the early 1900 s there were well known postgraduate 'colleges' based on the West London, Prince of Wales and Seaman's Hospitals, but they failed to survive the First World War. The Fellowship of Medicine was founded in 1918 and the next year amalgamated with the Postgraduate Medical Association under the presidency of Osler. Both the Athlone and Chamberlain Committees were discussing the provision of a postgraduate medical school in London throughout the 1920s. This was eventually set up at Hammersmith Hospital almost exactly 50 years ago (Calnan, 1985).

Postgraduate medical centres sprang up like mushrooms in the early 1960s; it would be interesting to know where they appeared first. Often planned and financed by local initiative, both professional and lay, there was a great deal of goodwill and pride in the centre. The basic design was a lecture theatre seating up to a hundred people, a library, a couple of offices and a seminar room. The more ambitious had a lounge/dining room with a bar, which could make a profit to pay for lecturers, books and equipment. The hospital helped with journal subscriptions, lecture fees, and the postgraduate secretary's salary, while one of the consultants acted as clinical tutor, with support from a postgraduate education committee.

There was very much an element of making do at first. We, in Birmingham, for example, had been holding courses in medicine, surgery and paediatrics, and general practitioner symposia (at weekends) in an unused paediatric ward, where our secretary occupied the linen cupboard. The Region wanted it back as a ward, so they built us a prefrabricated centre for $£ 18,000$ (early 1960s) as a quid pro quo. We went on mostly giving lectures, introduced weekly staff rounds and general practitioner meetings during lunch hours, and used the seminar room to supplement ward teaching for specialist qualifications. The key to success of the new style centres was undoubtedly the postgraduate secretary/administrator, a woman whose dedication has never been officially recognized and whose lack of status persists today. They have partly themselves to blame because they have not organized themselves into an effective group like librarians, for example, which could promote career prospects and proper salary scales; they have largely been content to act as administrators of their centres, arranging meetings, organizing speakers, contacting caterers and drug firm representatives, and dealing diplomatically with the demands of consultants, juniors, general practitioners, other health care workers and administrators. They have truly been the ambassadors of the postgraduate centres, and sadly have not always had the full support of clinical tutors.

The use of the centre has grown as medical education has become more professionalized; facilities have not necessarily kept pace with the demand. A striking example is the growth of general practitioner education and the need for vocational training schemes. Most colleges now have their own tutors who are responsible for their particular local training needs. And although some centres are not convinced that it is their job, many accommodate other health workers besides doctors and dentists, for example, pharmacists, pathology technologists, post-basic nurses, and administrators. Has anyone done a time and motion study of the usage of postgraduate centres?

The Department of Health's Building Note No 42 dated January 1985 is a large document devoted to the virtues and design of multidisciplinary education centres in new district general hospitals. It is called a draft and discussion document on which presumably the views of medical educationists are to be obtained. And yet it has been widely leaked, rumour has it, by the nursing hierarchy of the DHSS, and its suggestions have been incorporated in at least two of the Thames Regions' policy documents. This action has angered the medical establishment: many doctors feel that medical education should be treated as a special case and fear that its needs - sometimes mandatory to satisfy the requirements of university and colleges will not receive the necessary priority. It is ironic that while 25 years' experience of postgraduate medical 
education are used as a model by other professional groups, opposition by doctors to multidisciplinary provision will be seen as the reactionary response of a profession that wishes to keep the reins in its own hands.

There are obvious advantages in a large education centre. Main lecture hall, library and technical facilities, such as an audiovisual department, would be shared and a common room and bar would provide a meeting place for staff, as well as extra funds. The danger is that the need of doctors for education at irregular times will be overwhelmed by the more concentrated requirements of, say, student nurses. And is it practical to combine undergraduate (medical and nursing students, and perhaps others) and postgraduate education? It should be possible to compromise by allotting each discipline separate classrooms, seminar rooms, offices, and any other facilities required. An enlarged centre will need an administrator: the talk in official circles is of a bursar. Presumably the postgraduate secretary would continue to look after the medical interest, and predicted attempts to downgrade her function will have to be resisted. Perhaps she could forestall these efforts by becoming the new style Centre Administrator, a position for which her present expertise makes her ideally suited.

The work of postgraduate centres has changed in 25 years. Small group teaching, workshops, and staff meetings have replaced the more formal lectures and courses in importance, and in the future the emphasis is likely to be on evaluation, audit and performance

\section{References}

AllBUTT, T.C. (1906). On Professional Education with Special Reference to Medicine. Macmillan: London.

CALNAN, J. (1985). The Hammersmith 1935-1985. MTP

Press: Lancaster. review. Some centres have a research secretary, who can process information and provide tables, graphs and figures for talks or papers. Microcomputers are increasingly used for tasks other than merely word processing; centres with a special interest might consider putting on practical courses for their fellows.

The expertise and enthusiasm of the people who run the centre determines its success. Early clinical tutors were often reluctant to take on an additional chore and the job was given to the most junior consultant. They were amateurs who relied on an efficient secretary to do most of the work. If postgraduate medicine is to compete with other disciplines, future tutors will have to be both educationists and managers (with their own budget?); they will need the time and the money to do the job properly.

Alex Paton Postgraduate Dean North East Thames Region, British Postgraduate Medical Federation, 33 Millman Street, London WCIN $3 E J, U K$.

\section{Postscript}

Soon after writing this, I paid a visit to my old postgraduate centre (cost $£ 18,000$ you will remember) $\Omega$ now bulging at the seams. Planners at the DHSS, with grandiose schemes for education for all, might like to know that a proposed new 'education centre' is to cost $£ 1$ million, and it does not include the nursing school. 